\title{
NR4A2 and Schizophrenia: Lack of Association in a Portuguese/Brazilian Study
}

\author{
Dina Ruano, ${ }^{1,2}$ António Macedo, ${ }^{3}$ Ana Dourado, ${ }^{3}$ Maria João Soares, ${ }^{3}$ José Valente, ${ }^{3}$ Isabel Coelho, ${ }^{3}$ Vítor Santos, ${ }^{3}$ \\ Maria Helena Azevedo, ${ }^{3}$ Ann Goodman, ${ }^{4}$ Mara Helena Hutz, ${ }^{5}$ Clarissa Gama, ${ }^{6}$ Maria Inês Lobato, \\ Paulo Belmonte-de-Abreu, ${ }^{6}$ and Joana Almeida Palha ${ }^{1,2 *}$ \\ ${ }^{1}$ Health Sciences School, University of Minho, Braga, Portugal \\ ${ }^{2}$ Institute for Molecular and Cell Biology, Porto, Portugal \\ ${ }^{3}$ Instituto de Psicologia Médica, Faculdade de Medicina, Universidade de Coimbra, Coimbra, Portugal \\ ${ }^{4}$ Department of Psychiatry at Massachusetts Mental Health Center, Harvard Medical School, Boston \\ ${ }^{5}$ Departamento de Genética, Universidade Federal do Rio Grande do Sul, Porto Alegre, Brasil \\ ${ }^{6}$ Departmento de Psiquiatria, Universidade Federal do Rio Grande do Sul, Porto Alegre, Brasil
}

\begin{abstract}
The present study investigates the association of mutations in the nuclear receptor NR4A2 in schizophrenic patients. The human Nur-related receptor 1, NR4A2, is an orphan nuclear receptor that can be constitutively active as a transcription factor and for which no natural ligand has yet been identified. Alone or with retinoid $X$ receptor, RXR, NR4A2 influences the expression of several genes important for human brain development and regulation. In the absence of Nurr1 (the mouse homologue to human NR4A2), ventral mesencephalic dopaminergic mouse neurons evidence severe developmental failure, a condition that is lethal soon after birth. Nurr1 involvement in the dopaminergic system makes it a good candidate for study in neuropsychiatric disorders such as schizophrenia and Parkinson disease. Evidence by others support this hypothesis (1) mapping of the $N R 4 A 2$ gene to chromosome 2q22-23, a region with suggestive linkage to schizophrenia and (2) identification of mutations in patients with schizophrenia (c.366-369delTAC, c.308A $>$ G, c.-469delG), manic depression (c.289A $>$ G), and familial Parkinson's disease (c.-291delT, c.$245 T>G)$. To further extend these observations, we searched for all these mutations in 176 Caucasian Portuguese and 82 Caucasian Brazilian subjects with lifetime diagnosis of schizophrenia. The study failed to identify any of the described mutations in patients or controls. Nevertheless, these negative results do not exclude altered expression of nuclear receptors in schizophrenia or the presence of other mutations. (c) 2004 Wiley-Liss, Inc.
\end{abstract}

Part of this study has been presented in 10th World Congress on Psychiatric Genetics, Brussels, Belgium, October 2002.

Grant sponsor: Fundação para a Ciência e Tecnologia (Portugal); Grant number: POCTI/MGI/35837-FEDER; Grant sponsor: Conselho Nacional de Desenvolvimento Científico e Tecnológico (CNPq, BRASIL); Grant sponsor: GRICES (Portugal)/ CAPES (Brasil) exchange grant.

*Correspondence to: Joana Almeida Palha, Life and Health Sciences Research Institute, Health Sciences School, University of Minho, Campus de Gualtar, 4710-057 Braga, Portugal.

E-mail: japalha@ecsaude.uminho.pt

Received 8 September 2003; Accepted 23 December 2003

DOI 10.1002/ajmg.b.30031

\begin{abstract}
KEY WORDS: Nurr1; nuclear orphan receptor; dopamine; retinoids
\end{abstract}

\section{INTRODUCTION}

Schizophrenia is a chronic psychotic disorder of unknown etiology. Twin and family studies demonstrate a genetic basis for the disease [Tsuang et al., 2001]. Several genome wide studies identified chromosome loci consistently linked to increased susceptibility to schizophrenia in different populations [Lewis et al., 2003]. Despite the evidence for genetic predisposition, the lack of concordance in monozygotic twins implies that an epigenetic environmental effect is required for disease onset [Tsuang et al., 2001]. For this reason, interest has been raised in hypothesis bridging both genetic and environment-related mechanisms. Environmental factors such as hormones and vitamins interact with different nuclear receptors and interfere with the transcription of several genes on a developmental regulated fashion. Among these are the retinoids, considered good candidates because of genetic linkage studies implicating schizophrenia with disregulation of the retinoid cascade and/or genes whose expression they regulate [Goodman, 1998]. The genes for dopamine-2 receptor, synapsin, and dopamine $\beta$-hydroxylase are among those whose expression requires activation by retinoids [Samad et al., 1997; Kim et al., 2001, 2003; Balmer and Blomhoff, 2002]. Pharmacological, histological, and brain imaging data have for long implicated dopaminergic dysfunction in the etiology of schizophrenia. Retinoid availability can, therefore, interfere with susceptibility to schizophrenia, either directly, through the dopamine system, or indirectly through molecules involved in its development and/or regulation. Interestingly, retinoid analogs have been suggested in the treatment of schizophrenia, alone or in combination with dopamine receptor agonists [Citver et al., 2002].

Retinoic acid receptors belong to the steroid/thyroid hormone nuclear receptor superfamily that includes several orphan receptors for which no ligands have been identified. These receptors often act as heterodimers greatly increasing the complexity of gene regulation. NR4A2, one of these orphan nuclear receptors, is known to regulate transcription of target genes in two different ways: alone, as a monomer, or as a partner with the retinoid X receptor (RXR) [Perlmann and Jansson, 1995; Wang et al., 2003].

Nurr1 (the mouse homologue to human NR4A2 gene) mRNA is expressed very early in the ventral midbrain [Zetterström et al., 1996, 1997] and disruption of its expression is responsible for massive failure to generate dopaminergic neurons in the midbrain and causes death soon after birth [Zetterström 
et al., 1997; Saucedo-Cardenas et al., 1998]. The lack of dopaminergic neurons in the midbrain seems to be related with the inability to express tyrosine hydroxylase, the rate-limiting enzyme in dopamine synthesis [Zetterström et al., 1996]. Furthermore, Nurr 1 seems to retain its role in mature dopaminergic neurons, since its expression continues over adulthood and is extremely impaired after ventral mesencephalic dopaminergic neurons injury [Zetterström et al., 1996].

These observations increased the interest in identifying precise molecular and biochemical mechanisms of behavior regulation by NR4A2 in psychiatric and neurological disorders. Furthermore, the 2q22-q23 chromosome region that harbors the NR4A2 gene has suggestive linkage with schizophrenia in various populations [Moises et al., 1995; Williams et al., 1999; DeLisi et al., 2002; Lewis et al., 2003]. In accordance to this hypothesis several groups have looked for mutations in the NR4A2 human gene that could increase susceptibility to schizophrenia. Up to date, two deletions and one missense mutation have been described in schizophrenic patients and one missense mutation has been found in manicdepressed individuals [Buervenich et al., 2000; Chen et al., 2001] while, recently, two mutations in the untranslated region have been identified in patients with familial Parkinson's disease [Le et al., 2003]. These findings prompted us to investigate all these NR4A2 mutations in a large sample of Portuguese and Brazilian schizophrenic patients. Patients fulfilled DSM IV lifetime diagnosis of schizophrenia, confirmed by Operational Checklist for Psychotic Disorders (OPCRIT) diagnostic algorithm. None of the mutations described in the literature were identified in this group of patients.

\section{MATERIALS AND METHODS}

The sample consisted in 176 Portuguese (age range 15-74, average 34.0; 67 female and 109 male) and 82 Brazilian (age range 18-63, average $34.3 ; 10$ female and 72 male) schizophrenic patients and 105 Portuguese (age range 19-79, average 35.5 ; 53 female and 52 male) and 85 Brazilian (age range $19-58$, average 32.9 ; all men) mentally healthy individuals. All subjects were unrelated Caucasians. Patients gave informed consent for the study, and ethic committees of both institutions approved the study. All patients (Portuguese and Brazilian) were classified by the OPCRIT system [McGuffin and Farmer, 2001]. OPCRIT automated system gathered information from all case records, including medical, nursing, social work and occupational therapy notes together with data from clinical interview with patient and relatives. Additionally, Portuguese schizophrenic patients received lifetime diagnosis using DIGS (Diagnostic Interview for Genetic Studies) as previously described [Nurnberger et al., 1994]. Controls were from European origin or descent and free of any lifetime diagnosis of major mental illness and physical illness. Portuguese controls received DIGS assessment and Brazilian controls were selected among blood bank volunteer donors documented to be free of chemical dependence [Rios et al., 2003]. All interviews and diagnostic formulations were performed by one of the authors. Venous blood was drawn from all subjects and DNA extracted using standard saltingout procedures.

For genotyping the c.-245T $>\mathrm{G}$, c.289 A>G, c.308 A>G mutations and the deletion c.-469delG, we followed PCR conditions previously described [Buervenich et al., 2000; Chen et al., 2001; Le et al., 2003]. PCR products were analyzed on gel electrophoresis after digestion with the restriction enzymes Ava II (Fermentas, Vilnius, Lithuania), ApaL I (Fermentas), Tse I (New England BioLabs, Beverly, MA), and Cfr I (Fermentas), respectively. The c.366-369delTAC deletion was screened by single strand conformation polymorphism (SSCP) on the PCR product amplified with the primers $\left(5^{\prime}-3^{\prime}\right)$
CTTGTACCAAATGCCCCTGT and GAGACTGGCGTTTTCCTCT. Electrophoresis on $10 \%$ non-denaturing polyacrylamide gel with $2.5 \%$ glycerol was performed at $500 \mathrm{~V}$ for $2.5-3$ $\mathrm{hr}$. Temperature was strictly maintained at $14^{\circ} \mathrm{C}$. Samples from patient carriers of the mutations c.366-369delTAC, c.289 $\mathrm{A}>\mathrm{G}$, and c. $308 \mathrm{~A}>\mathrm{G}$ were used as controls.

Search for the c.-291delT on the PCR product amplified with primers previously described [Le et al., 2003] was done by SSCP analysis on MDE gel (Cambrex Bio Science Rockland, Rockland, ME) run at 4,10 , or $25^{\circ} \mathrm{C}$.

\section{RESULTS}

Using SSCP analysis, we searched the deletions c.366369delTAC and c.-291delT, looking also for other possible mutations [Vidal-Puig and Moller, 1994] on the same PCR product. Figure 1 shows the SSCP migration pattern of a c.366369delTAC deletion carrier. None of the sample tested revealed the presence of mutated alleles.

For the c.-291delT deletion we analyzed one subpopulation of 60 Portuguese schizophrenic patients and run the SSCP at three different temperatures to increase the rate of detection. Again, we failed to identify any mutation in the PCR product containing the position c.-291. Analysis of the mutations c.$469 \mathrm{delG}$, c.-245T $>$ G, c. $289 \mathrm{~A}>\mathrm{G}$, and c.308A $>$ G was done by digestion with the enzymes Cfr I, Ava II, ApaL I, and Tse I for which a new restriction site is present in the mutated allele. None of the samples, from schizophrenic or mentally healthy individuals, contained any of the mutations screened.

Table I is a summary of all studies, including ours, in which NR4A2 mutations described in diseases have been investigated.

\section{DISCUSSION}

In the present study we investigated, for the first time, the presence of two NR4A2 mutations recently identified in familial Parkinson's disease [Le et al., 2003] in 258 schizophrenic patients and 190 mentally healthy individuals. We also searched for mutations in the NR4A2 previously described in patients with schizophrenia and manic-depression [Buervenich et al., 2000; Chen et al., 2001]. No mutation was found either in patients or controls. Given the complex etiology of schizophrenia and the failure to identify a single causative gene, it is unlikely that any individual mutation will be strongly represented in the patient's population [Chakravarti, 1999]. In the case of transcription factors such as nuclear receptors, several different mutations can impair proper function and influence the appropriate expression of several genes. Therefore, for any new mutation found it is important to increase the size of the patient sample analyzed. The fact that

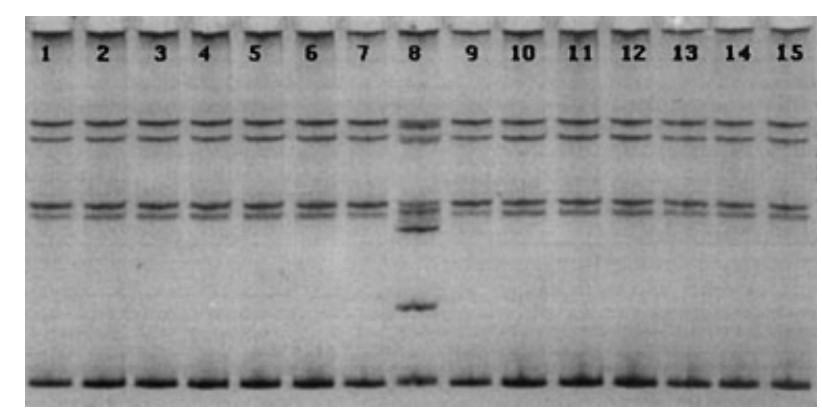

Fig. 1. Single strand conformation polymorphism (SSCP) analysis of the NR4A2 exon 3 PCR fragment. On lane 8 run a sample containing the c. 366 369delTAC mutation. Lanes 1-6 correspond to Brazilian schizophrenic patients and lanes 7, 9-15 to Brazilian mentally healthy individuals. 
TABLE I. NR4A2 Mutations Detected in Patients With Schizophrenia, Manic Depression, and Parkinson's Disease

\begin{tabular}{|c|c|c|c|}
\hline Mutation & Location & Population & In vitro transcription activity \\
\hline c. -469 delG & Promoter & $\begin{array}{l}\text { 2/176 Han Chinese schizophrenic } \\
\text { [Chen et al., 2001] } \\
\text { 0/176 Caucasian Portuguese schizophrenic } \\
\text { 0/82 Caucasian Brasillan schizophrenic }\end{array}$ & Not determined \\
\hline c.-291 delT & Exon 1, untranslated & $\begin{array}{l}\text { 8/107 familial }+0 / 94 \text { sporadic Parkinson's } \\
\text { (mostly Caucasian) [Le et al., 2003] } \\
\text { 0/60 Caucasian Portuguese schizophrenic }\end{array}$ & Decreased [Le et al., 2003] \\
\hline c. $-245 \mathrm{~T}>\mathrm{G}$ & Exon 1, untranslated & $\begin{array}{l}\text { 2/107 familial + 0/94 sporadic Parkinson's } \\
\text { (mostly Caucasian) [Le et al., 2003] } \\
\text { 0/176 Caucasian Portuguese schizophrenic } \\
\text { 0/82 Caucasian Brasilian schizophrenic }\end{array}$ & Decreased [Le et al., 2003] \\
\hline c. $289 \mathrm{~A}>\mathrm{G}$ & Exon 3, coding & $\begin{array}{l}\text { 0/135 Swedish schizophrenics } \\
\text { [Buervenich et al., 2000] } \\
\text { 0/160 North American Caucasian } \\
\text { schizophrenics [Buervenich et al., 2000] } \\
\text { 0/70 Caucasian Swedish idiopathic Parkinson } \\
\text { [Buervenich et al., 2000] } \\
\text { 1/30 Caucasian Swedish manic depressed } \\
\text { [Buervenich et al., 2000] } \\
\text { 0/176 Caucasian Portuguese schizophrenic } \\
\text { 0/82 Caucasian Brasilian schizophrenic }\end{array}$ & Decreased [Buervenich et al., 2000] \\
\hline c. $308 \mathrm{~A}>\mathrm{G}$ & Exon 3, coding & $\begin{array}{l}\text { 1/135 Swedish schizophrenics } \\
\text { [Buervenich et al., 2000] } \\
\text { 0/160 Caucasian North American } \\
\text { schizophrenics [Buervenich et al., 2000] } \\
\text { 0/70 Caucasian Swedish Idiopathic Parkinson } \\
\text { [Buervenich et al., 2000] } \\
\text { 0/30 Caucasian Swedish manic depressed } \\
\text { [Buervenich et al., 2000] } \\
\text { 0/176 Caucasian Portuguese schizophrenic } \\
\text { 0/82 Caucasian Brasilian schizophrenic }\end{array}$ & Decreased [Buervenich et al., 2000] \\
\hline c.366-369 del TAC & Exon 3, coding & $\begin{array}{l}1 \text { childhood-onset/135 Caucasian Swedish } \\
\text { schizophrenics [Buervenich et al., 2000] } \\
\text { 0/160 Caucasian North American } \\
\text { schizophrenics [Buervenich et al., 2000] } \\
\text { 0/70 Caucasian Swedish Idiopathic Parkinson } \\
\text { [Buervenich et al., 2000] } \\
\text { 0/30 Caucasian Swedish manic depressed } \\
\text { [Buervenich et al., 2000] } \\
\text { 0/176 Caucasian Portuguese schizophrenic } \\
\text { 0/82 Caucasian Brasilian schizophrenic }\end{array}$ & Decreased [Buervenich et al., 2000] \\
\hline
\end{tabular}

Represented is the number of individuals in which NR4A2 mutations were found among all patients tested.

we failed to identify the mutations previously described confirms that they are very rare in NR4A2 gene.

Other studies have reported lack of association of NR4A2 polymorphic variants in the promoter [Carmine et al., 2003], $5^{\prime}$ and $3^{\prime}$ untranslated regions and intron 6 with schizophrenia [Ishiguro et al., 2002; Iwayama-Shigeno et al., 2003].

The human NR4A2 gene exists as a single locus in human genome, covering $8.3 \mathrm{~Kb}$ in length, consisting of eight exons and is mapped to chromosome 2q22-23 [Ichinose et al., 1999; Torii et al., 1999]. This chromosome region has been implicated in schizophrenia [Lewis et al., 2003]. The mutations c. $289 \mathrm{~A}>\mathrm{G}, \mathrm{c} .308 \mathrm{~A}>\mathrm{G}$, and c.366-369delTAC, originate amino acid changes at the protein level (M97V, H103R, and $\Delta \mathrm{Y} 122$, respectively) and result in decreased in vitro transcriptional activity of NR4A2 dimmers [Buervenich et al., 2000]. Decreased transcription activity of the NR4A2 is also described for the mutations in the $5^{\prime}$ untranslated region found in patients with Parkinson's disease [Le et al., 2003]. Therefore, impaired transcription activation of downstream target genes such as tyrosine hydroxylase is expected in carriers of these mutant variants of NR4A2.

Studies in mice have revealed important functions for NR4A2 that clearly suggest its possible involvement in several disorders of the central nervous system in which the dopaminergic system has been implicated. Observations in Nurr1-null mice revealed that Nurr1 is requested for the formation of midbrain dopaminergic neurons [Zetterström et al., 1997; Saucedo-Cardenas et al., 1998] and that tyrosine hydroxylase, the rate-limiting enzyme in the cathecolaminergic pathway, is absent in dopaminergic neurons [Zetterström et al., 1997]. On the other hand, mice lacking the D2 receptors for dopamine show increase Nurr1 expression in mesencephalic dopaminergic neurons, suggesting that actions mediated by $\mathrm{D} 2$ receptors might be a consequence of altered expression of Nurr1 [Tseng et al., 2000]. In addition, Nurr 1 enhances the transcription of the human dopamine transporter gene [Sacchetti et al., 2001], one of the most specific phenotypic markers for dopaminergic neurons, and of the tyrosine hydroxylase gene [Sakurada et al., 1999; Kim et al., 2001, 2003]. Studies in Nurr1-null heterozygous mice show that Nurr1 increases spontaneous locomotor activity in response to stress [Eells et al., 2002]. The effect of amphetamines in Nurr1-null heterozygous locomotion remains controversial [Eells et al., 2002; Bäckman et al., 2003].

These observations suggest that NR4A2 by itself, or through heterodimerization partners, may participate in diseases with altered dopaminergic function such as Parkinson's, 
schizophrenia, and drug abuse. NR4A2 may also be implicated in some personality traits with increased vulnerability to stress [Eells et al., 2002] such as those in the schizophrenia phenotype spectrum. Both mutations associated with decreased or increased NR4A2 activity and with altered regulation of the NR4A2 gene throughout development might be associated with disorders such as schizophrenia and Parkinson's. Future studies must address whether the expression of NR4A2 is altered in the brain of schizophrenic patients or influences their response to alcohol exposure or drug treatment. Better understanding of the pathways involving NR4A2 might make it a potential target for therapy with drugs like 6-mercaptopurine analogs or even stem-cell transplants as recently suggested [Ordentlich et al., 2003].

\section{ACKNOWLEDGMENTS}

We want to thank Dr. Silvia Buervenich for kindly providing DNA samples with the mutations c.289A $>$ G, c.308A $>$ G, and c.366-369delTAC, and Dr. Wei-dong Le for providing the PCR primer sequences for the fragments containing mutations c.291delT and c. $-245 \mathrm{~T}>\mathrm{G}$. Dina Ruano is a recipient of a Ph.D fellowship from Fundação para a Ciência e Tecnologia (Portugal).

\section{REFERENCES}

Balmer JE, Blomhoff R. 2002. Gene expression regulation by retinoic acid. $J$ Lipid Res 43:1773-1808.

Buervenich S, Carmine A, Arvidsson M, Xiang F, Zhang Z, Sydow O, Jönsson EG, Sedvall GC, Leonard S, Ross RG, Freedman R, Chowdari KV, Nimgaonkar VL, Perlmann T, Anvret M, Olson L. 2000. NURR1 mutations in cases of schizophrenia and manic-depressive disorder Am J Med Genet 96:808-813.

Bäckman C, You ZB, Perlmann T, Hoffer BJ. 2003. Elevated locomotor activity without altered striatal dopamine contents in Nurr1 heterozygous mice after acute exposure to methamphetamine. Behav Brain Res 143:95-100

Carmine A, Buervenich S, Galter D, Jönsson EG, Sedvall GC, Farde L, Gustavsson JP, Bergman H, Chowdari KV, Nimgaonkar VL, Anvret M, Sydow O, Olson L. 2003. NURR1 promoter polymorphisms: Parkinson's disease, schizophrenia, and personality traits. Am J Med Genet 120 51-57.

Chakravarti A. 1999. Population genetics-making sense out of sequence. Nat Genet 21:56-60.

Chen YH, Tsai MT, Shaw CK, Chen CH. 2001. Mutation analysis of the human NR4A2 gene, an essential gene for midbrain dopaminergic neurogenesis, in schizophrenic patients. Am J Med Genet 105:753757.

Citver AS, Shields AM, Ciaccia LM, Schulingkamp RJ, Raffa RB. 2002. Indirect modulation of dopamine D2 receptors as potential pharmacotherapy for schizophrenia: III. Retinoids. J Clin Pharm Ther 27:161168.

DeLisi LE, Mesen A, Rodriguez C, Bertheau A, LaPrade B, Llach M, Riondet S, Razi K, Relja M, Byerley W, Sherrington R. 2002. Genome-wide scan for linkage to schizophrenia in a Spanish-origin cohort from Costa Rica. Am J Med Genet 114:497-508.

Eells JB, Lipska BK, Yeung SK, Misler JA, Nikodem VM. 2002. Nurr1-null heterozygous mice have reduced mesolimbic and mesocortical dopamine levels and increased stress-induced locomotor activity. Behav Brain Res 136:267-275.

Goodman AB. 1998. Three independent lines of evidence suggest retinoids as causal to schizophrenia. Proc Natl Acad Sci USA 95:7240-7244.

Ichinose H, Ohye T, Suzuki T, Sumi-Ichinose C, Nomura T, Hagino Y, Nagatsu T. 1999. Molecular cloning of the human Nurr1 gene: Characterization of the human gene and cDNAs.. Gene 230:233-239.

Ishiguro H, Okubo Y, Ohtsuki T, Yamakawa-Kobayashi K, Arinami T. 2002. Mutation analysis of the retinoid $\mathrm{X}$ receptor beta, nuclear-related receptor 1 , and peroxisome proliferator-activated receptor alpha genes in schizophrenia and alcohol dependence: Possible haplotype association of nuclear-related receptor 1 gene to alcohol dependence. Am J Med Genet 114:15-23.
Iwayama-Shigeno Y, Yamada K, Toyota T, Shimizu H, Hattori E, Yoshitsugu K, Fujisawa T, Yoshida Y, Kobayashi T, Toru M, Kurumaji A, Detera-Wadleigh S, Yoshikawa T. 2003. Distribution of haplotypes derived from three common variants of the NR4A2 gene in Japanese patients with schizophrenia. Am J Med Genet 118:20-24.

Kim HS, Hong SJ, LeDoux MS, Kim KS. 2001. Regulation of the tyrosine hydroxylase and dopamine beta-hydroxylase genes by the transcription factor AP-2. J Neurochem 76:280-294.

Kim KS, Kim CH, Hwang DY, Seo H, Chung S, Hong SJ, Lim JK, Anderson T, Isacson O. 2003. Orphan nuclear receptor Nurr1 directly transactivates the promoter activity of the tyrosine hydroxylase gene in a cellspecific manner. J Neurochem 85:622-634.

Le WD, Xu P, Jankovic J, Jiang H, Appel SH, Smith RG, Vassilatis DK. 2003. Mutations in NR4A2 associated with familial Parkinson disease. Nat Genet 33:85-89.

Lewis CM, Levinson DF, Wise LH, DeLisi LE, Straub RE, Hovatta I, Williams NM, Schwab SG, Pulver AE, Faraone SV, Brzustowicz LM, Kaufmann CA, Garver DL, Gurling HM, Lindholm E, Coon H, Moises HW, Byerley W, Shaw SH, Mesen A, Sherrington R, O’Neill FA, Walsh D, Kendler KS, Ekelund J, Paunio T, Lönnqvist J, Peltonen L, O'Donovan MC, Owen MJ, Wildenauer DB, Maier W, Nestadt G, Blouin JL, Antonarakis SE, Mowry BJ, Silverman JM, Crowe RR, Cloninger CR, Tsuang MT, Malaspina D, Harkavy-Friedman JM, Svrakic DM, Bassett AS, Holcomb J, Kalsi G, McQuillin A, Brynjolfson J, Sigmundsson T, Petursson H, Jazin E, Zoëga T, Helgason T. 2003. Genome scan metaanalysis of schizophrenia and bipolar disorder, part II: Schizophrenia. Am J Hum Genet 73:34-48.

McGuffin P, Farmer A. 2001. Polydiagnostic approaches to measuring and classifying psychopathology. Am J Med Genet 105:39-41.

Moises HW, Yang L, Kristbjarnarson H, Wiese C, Byerley W, Macciardi F, Arolt V, Blackwood D, Liu X, Sjogren B, Aschauer HN, Hwu HG, Jang K, Livesley WJ, Kennedy JL, Zoega T, Ivarsson O, Bui MT, Yu MH, Havsteen B, Commenges D, Weissenbach J, Schwinger E, Gottesman II, Pakstis AJ, Wetterberg L, Kidd KK, Helgason T. 1995. An international two-stage genome-wide search for schizophrenia susceptibility genes. Nat Genet 11:321-324

Nurnberger JI Jr, Blehar MC, Kaufmann CA, York-Cooler C, Simpson SG, Harkavy-Friedman J, Severe JB, Malaspina D, Reich T. 1994. Diagnostic interview for genetic studies. Rationale, unique features, and training. NIMH Genetics Initiative. Arch Gen Psychiatry 51:849859 .

Ordentlich P, Yan Y, Zhou S, Heyman RA. 2003. Identification of the antineoplastic agent 6-mercaptopurine as an activator of the orphan nuclear hormone receptor Nurr1. J Biol Chem 278:2479124799.

Perlmann T, Jansson L. 1995. A novel pathway for vitamin A signaling mediated by RXR heterodimerization with NGFI-B and NURR1. Genes Dev 9:769-782

Rios DL, Vargas AF, Torres MR, Zago AJ, Callegari-Jacques SM, Hutz MH. 2003. Interaction between SREBP-1a and APOB polymorphisms influences total and low-density lipoprotein cholesterol levels in patients with coronary artery disease. Clin Genet 63:380-385.

Sacchetti P, Mitchell TR, Granneman JG, Bannon MJ. 2001. Nurr1 enhances transcription of the human dopamine transporter gene through a novel mechanism. J Neurochem 76:1565-1572.

Sakurada K, Ohshima-Sakurada M, Palmer TD, Gage FH. 1999. Nurr1, an orphan nuclear receptor, is a transcriptional activator of endogenous tyrosine hydroxylase in neural progenitor cells derived from the adult brain. Development 126:4017-4026.

Samad TA, Krezel W, Chambon P, Borrelli E. 1997. Regulation of dopaminergic pathways by retinoids: Activation of the D2 receptor promoter by members of the retinoic acid receptor-retinoid $\mathrm{X}$ receptor family. Proc Natl Acad Sci USA 94:14349-14354.

Saucedo-Cardenas O, Quintana-Hau JD, Le WD, Smidt MP, Cox JJ, De Mayo F, Burbach JP, Conneely OM. 1998. Nurr1 is essential for the induction of the dopaminergic phenotype and the survival of ventral mesencephalic late dopaminergic precursor neurons. Proc Natl Acad Sci USA 95:4013-4018.

Torii T, Kawarai T, Nakamura S, Kawakami H. 1999. Organization of the human orphan nuclear receptor Nurr1 gene. Gene 230:225-232.

Tseng KY, Roubert C, Do L, Rubinstein M, Kelly MA, Grandy DK, Low MJ, Gershanik OS, Murer MG, Giros B, Raisman-Vozari R. 2000. Selective increase of Nurr1 mRNA expression in mesencephalic dopaminergic neurons of D2 dopamine receptor-deficient mice. Brain Res Mol Brain Res 80:1-6. 
Tsuang MT, Stone WS, Faraone SV. 2001. Genes, environment and schizophrenia. Br J Psychiatry 40:s18-s24.

Vidal-Puig A, Moller DE. 1994. Comparative sensitivity of alternative single-strand conformation polymorphism (SSCP) methods. Biotechniques 17:490-496.

Wang Z, Benoit G, Liu J, Prasad S, Aarnisalo P, Liu X, Xu H, Walker NP Perlmann T. 2003. Structure and function of Nurr1 identifies a class of ligand-independent nuclear receptors. Nature 423:555-560.

Williams NM, Rees MI, Holmans P, Norton N, Cardno AG, Jones LA, Murphy KC, Sanders RD, McCarthy G, Gray MY, Fenton I, McGuffin P,
Owen MJ. 1999. A two-stage genome scan for schizophrenia susceptibility genes in 196 affected sibling pairs. Hum Mol Genet 8:1729-1739.

Zetterström RH, Williams R, Perlmann T, Olson L. 1996. Cellular expression of the immediate early transcription factors Nurr1 and NGFI-B suggests a gene regulatory role in several brain regions including the nigrostriatal dopamine system. Brain Res Mol Brain Res 41:111120 .

Zetterström RH, Solomin L, Jansson L, Hoffer BJ, Olson L, Perlmann T. 1997. Dopamine neuron agenesis in Nurr1-deficient mice. Science $276: 248-250$. 